\title{
Phytochemical Constituents, Safety and Efficacy Study of Thymus schimperi and Thymus serrulatus
}

\author{
Abera T* Debebe E, Ashebir R, Abebe A, Basha H, Kasahun T and Sisay B \\ Traditional and Modern Medicine Research Directorate, Ethiopian Public Health Institute, Addis Ababa, Ethiopia
}

\begin{abstract}
Background: The genus Thymus is one of the most taxonomically complex genera in the Lamiaceae family and it includes 250 350 taxa (species and varieties). T. serrulatus Hochst. ex Benth and T. schimperi Ronniger are the two species of thymus which are endemic to Ethiopia; locally known as Tosign. According to WHO 2018 report, NCDs (non-communicable disease) are estimated to account for 39\% of all deaths in Ethiopia and Infectious diseases also represent a continuous and increasing threat to human health in developing countries like Ethiopia. In Ethiopia, $80 \%$ of the population use plant remedies or medicinal plants over centuries.
\end{abstract}

Objective: The present study aimed to review Phytochemical-constituents, Safety and Efficacy Study of Thymus schimperi and Thymus Serrulatus.

Method: A web-based literature search was done by using scientific databases including Pub Med, Science Direct, Google Scholar and Scopus. Searching was made using key words: Thymus, Thymus schimperi, Thymus serrulatus, phytochemistry, pharmacology, ethnomedicine, efficacy and safety.

Results: T. serrulatus grows in Tigray, Gondar, Bale, in the highlands of Semien Shoa and Wollo whereas T. schimperi is widely distributed in Oromia, Amhara and Southern Nations Nationalities \& Peoples Regions. T. serrulatus and T. schimperi belong to the chemotypes Carvacrol-Thymol. Carvacrol (63\%), thymol (36\%-38\%), Thymol (49\%) are the major constituent of the essential oil of T. schimperi collected from Bale, T. schimperi from Gonder, Shewa \& Wello, T. serrulatus from the Tigray region respectively. Treatment of mice with $2000 \mathrm{mg} / \mathrm{kg}$ dose of the essential oil of T. schimperi caused $50 \%$ mortality indicating that it's the LD50 is about $2000 \mathrm{mg} / \mathrm{kg}$. However, n-butanol fraction of the aqueous and crude methanol leaf extract T. serrulatus with the oral limit dose of $5,000 \mathrm{mg} / \mathrm{kg}$ showed no sign of overt behavioral changes and toxicity where the LD50 were above $10,000 \mathrm{mg} / \mathrm{kg}$. n-butanol fraction and the crude aqueous extract of T. serrulatus has exhibited an increase in urine volume with the highest urine output at the highest dose $(1,000 \mathrm{mg} / \mathrm{kg})$ and an appreciable diuretic activity of $94 \%$ and $92 \%$ respectively.

Conclusion and Recommendation: The essential oil of T. schimperi did not cause a rise in serum enzyme level and major organ damage (kidney and liver), but the dose range of $2000 \mathrm{mg} / \mathrm{kg}$ causes $50 \%$ mortality. The n-butanol fraction of crude aqueous leaf extract of T. serrulatus showed an increase in urine volume with the highest urine output at the highest dose $(1,000 \mathrm{mg} / \mathrm{kg}) \mathrm{and}$ appreciable diuretic activity (94\%). Additional chemical isolation, development of dosage form, clinical trial and toxicological study is recommended.

Keywords: Thymus serrulatus; Thymus schimperi; Efficacy; Safety; Ethnomedicine

\section{INTRODUCTION}

The genus Thymus is one of the most taxonomically complex genera in the Lamiaceae family. It includes 250-350 species and varieties of wild growing evergreen species of herbaceous perennials, subshrubs and aromatic [1,2]. The Thymus species in Eritrea and Ethiopia are restricted to Afromontane and afro alpine regions the species are well known medicinal plants because of their biological and pharmacological properties [3]. Thyme is largely distributed in temperate zones where Ethiopia has considerably abundant
Lamiaceae family herb growing at different regions possessing a variety of the wild growing species of this family.

The two species, T. serrulatus Hochst. ex Benth and T. schimperi Ronniger, both locally known as Tosign, which are endemic species represented in Ethiopia [4-7]. They grow in an open grassland, edges of roads, on bare rocks and on slopes, in the altitude range of 2200-4000 m [8,9].

According WHO 2018 report, NCDs (non-communicable diseases) are estimated to account for $39 \%$ of all deaths in Ethiopia

*Correspondence to: Abera T, Assistant Researcher, Traditional and Modern Medicine Research Directorate, Ethiopian Public Health Institute, Addis Ababa, Ethiopia, E-mail:tigistabera1664@gmail.com

Received: July 06, 2019; Accepted: September 04, 2019; Published: September 10, 2019

Citation: Abera T, Debebe E, Ashebir R, Abebe A, Basha H, Kasahun T, et al. (2019) Phytochemical Constituents, Safety and Efficacy Study of Thymusschimperi and Thymus serrulatus. J Clin Exp Pharmacol 10: 263. doi: 10.35248/2161-1459.19.10.263

Copyright: (C) 2019 Abera T, et al. This is an open-access article distributed under the terms of the Creative Commons Attribution License, which permits unrestricted use, distribution, and reproduction in any medium, provided the original author and source are credited. 
which was $16 \%$ due to cardiovascular diseases and hypertension, is the prominent risk factor for chronic kidney disease, coronary heart disease and ischemic, as well as stroke and hemorrhagic [10]. Infectious diseases also represent a continuous and increasing threat to human health and developing countries like Ethiopia are carrying the major part of the burden. The number of infections caused by new, reemerging or drug resistant pathogens is growing from time to time. So, to fill such gaps in which new antimicrobial agents are urgently needed [11].

$80 \%$ of the population of Ethiopia use plant remedies or medicinal plants over centuries. Moreover, medicinal plants remain the most crucial or sometimes the only source of therapeutics by playing a key role in the increase and progress of modern studies by being a base for the development of novelties in drugs [1216]. In indigenous communities like Africa, Plants have played a central part in combating many ailments both in human and livestock. In Ethiopia, the plant based health care endures as the main alternative treatment for different ailments, mainly due to the scarcity of modern medicine, absence of nearby health service stations, expensive prices of conventional drugs for small holder farmers and pastoralists, appearance of drug resistant microbes and/or helminthes and emergence $\&$ recurrence of certain diseases [17-19].

Many of the modern pharmaceuticals are derived from medicinal herbs. Some of these include digitalis, a heart medication, derived from the Foxglove plant; salicylic acid, the source of aspirin, from Willow bark; and taxol for treating ovarian cancer, from the Pacific Yew tree, quinine and artemisinin are also well known antimalarial drugs derived from the bark of Cinchona tree and Artemisia annua, respectively $[20,21]$. In Ethiopia, the dried leaves of T. serrulatus and T. schimperi are used as traditional medicine for the treatment of headache, cough, stomachache, earache, liver disease and gonorrhea. They are also used as flavor tea, coffee and different kinds of stew [5].

In Ethiopia T. schimperi possesses antibacterial, anthelmintic and antifungal activity $[8,11,22]$. It is also one of the most widely used medicinal plants for the treatment of renal diseases, hypertension, inflammation, infections, pain, to wash skin, mouth wash. The essential oil from leaves of T. serrulatus is used as for the treatment of hypertension, renal diseases and used as diuretic, anthelmintic, disinfectant, antispasmodic, carminative, deodorant, diaphoretic, expectorant, sedative, tonic, anti-inflammatory, antimicrobial, antibacterial, antifungal, antiviral, germicidal and libido enhancer [7,8,22]. Historically, In Ethiopia, there are documentations of T. schimperi and T. serrulatus used traditionally for the treatment of different human diseases in different parts of the country. However, the preclinical study such as phytochemical constituents, safety, efficacy and pharmacologic property of T. schimperi and T. serrulatus are not well reviewed in detail from different literature. Therefore, the aim of this study is to review the phytochemistry, efficacy and safety of T. serrulatus and T. schimperi.

\section{Description of the plant species T. schimperi and T. serrulatus}

T. schimperi Ronniger and T. serrulatus Hochst. ex Benth are perennial herbs, woody at the base and $5-40 \mathrm{~cm}$ high. The inflorescence is commonly crowded into globose and oblong heads with pink corollas [9]. T. schimperi is widely grown in different part of Ethiopia such as in Oromia, Amhara and Southern Nations Nationalities
\& Peoples Regions. It is found in Ankober, Denkoro forest, Chancho, Menz Gera Midir (Guassa) Tarma Ber wereda of North Shewa and Gondar areas. T. schimperi is found in Dinsho, Sanetti Mountains, Adaba Dodola, Goma, Asendabo Jimma zone, Debre Zeyit, National Park of Awash and Menagesha Suba State Forest [5,23]. According to Shewaye, et al. [3] T. schimperi occurs in the wild at high altitudes such as in Debre Sina and Bale mountains. T. serrulatus is distributed around Bale, in the highlands of Semien Shoa, in Tigray, Wollo and Gonder [5,9,23-25].

\section{Phytochemistry of Thymus schimperi and Thymus serrulatus}

Thyme oils contain phytochemicals such as carvacrol, thymol, $\gamma$-terpinene, and p-cymene. These phytoconstituents are present in various proportions and characterized by a large amount of monoterpenes which accounts for $90 \%$ of the oil. Thymol and carvacrol occur more commonly and accompanied by the couple c-terpinene/p-cymene, the four monoterpenes being biogenetically closely correlated $[1,26]$. The presence of intraspecific chemotype variation being common in the genus Thymus. Each of the six chemotypes; thymol, carvacrol, geraniol, $\alpha$-terpineol, thuyanol-4 and linalool are named after its major constituent monoterpene [27,28]. T. serrulatus and T. schimperi belong to the thymol-carvacrol chemotypes [26]. Both the chemical composition and the isolation yield of thyme oils depend on a number of factors, such as the environment or region in which they are grown, the practice in cultivation, the development stage of the plant, harvesting time and habitat $[1,6,28,29]$.

T. schimperi from Bale is composed of carvacrol (63\%) as the major constituent whereas T. schimperi from Gonder, Shewa and Wello is composed of thymol (36\%-38\%) as a dominant phytoconstituent. The essential oil of T. serrulatus collected from the Tigray region had thymol (49\%) as the major constituent, similar to T. shimperi which is found around Dinsho [5,6]. However, the essential oil of T. schimperi collected from medicinal market of Merkto was analyzed to contain thymol (56.5\%), linalool (18.5\%), and carvacrol (8.9\%) as major constituents [3]. According to Ermias, et al. [6] the essential oil of T. schimperi which is grown in Addis Ababa is rich in carvacrol (66.2\%) and $\gamma$-terpinene (13.2\%). Destaw, et al. [30] also reported the chemical composition of six essential oils of T. serrulatus and T. schimperi from six localities in Ethiopia, namely Ofla, Alamata, Yilmana Densa, Tarmaber, Butajira and Bale. According to the report of Destaw the major components of essential oil from Ofla are Alamata's thymol (65.6\%), thymol (49.6\%), Yilmana Densa's carvacrol (80.4\%), Tarmaber's thymol (48.8\%), Carvacrol (71.8\%) were the prominent components of the essential oil from Butajira and in the case of Bale were thymol (53.6\%). He also studied that T. serrulatus from Alamata and Ofla, T. schimperi from Bale and Tarmaber are of thymol chemotypes. The other two T. serrulatus from Yilmana Densa and T. schimperi of Butajira were found to contain carvacrol chemotypes. T. schimperi and T. serrulatus essential oil contains similar components with other species of thyme, The major components of thymus vulgaris from Romania were thymol $(47.59 \%)$ and $\gamma$-terpinene $(30.90 \%)$, which indicates that the essential oil analyzed belongs to the thymol chemotype. Carvacrol and thymol were the major compounds found in essential oils of T. capitata and T. zygis from Spain, respectively $[27,28,31]$. The crude extract and powdered plant leaves of T. schimperi is composed of secondary metabolites; tannins, phenols and saponins as major constituents [32]. 
The crude extracts and solvent fractions of $T$. serrulatus leaves have been reported by Amelework, et al. [25] to contain different secondary metabolites. Alkaloids, Saponins, Polyphenols, Tannins and Phytosterols were found in aqueous crude leaf extract of T. serrulatus. Saponins, flavonoids tannins and phytosterols were found in dichloromethane fraction of aqueous crude leaf extracts of T. serrulatus. n-butanol fraction of crude aqueous leaf extract of T. Serrulatus is composed of alkaloids, saponins, polyphenols, tannins and phytosterols which was comparable with the secondary metabolites of hexane, ethyl acetate, chloroform, butanol and methanol leaves extracts of T. vulgaris [33]. Aqueous and $80 \%$ methanol crude extract of $T$. schimperi leaves was qualitatively analyzed and the presence of steroids, alkaloids, flavonoids, saponins and tannins has been detected [34]. The other report showed that the wild Abyssinian thyme aerial parts the flower had highest total phenolic content $(0.5 \mu \mathrm{g} / \mathrm{ml})$ and the leaf the lowest and the whole thyme plant had the highest condensed tannin content $(0.9 \mu \mathrm{g} / \mathrm{ml})$. Distribution of macro and micro nutrients in T. schipmeri Ca $(2,776 \pm 130 \mu \mathrm{g} / \mathrm{g})$ was observed to be of the highest concentration followed by $\mathrm{Mg}(1,786 \pm 13 \mu \mathrm{g} / \mathrm{g})$. From the studied microelements, Fe $(728 \pm 58 \mu \mathrm{g} / \mathrm{g})$ was found in a significant amount compared to $\mathrm{Mn}, \mathrm{Co}, \mathrm{Cu}, \mathrm{Zn}, \mathrm{Ni}$, and $\mathrm{Cd}[35,36]$.

\section{Safety of T. schimperi and T. serrulatus}

Kassahun, et al. [37] acute toxicity study on mice revealed that the essential oil of T. schimperi causes depression, shivering, loss of balance and abnormal body movements. Mice treated with 2000 $\mathrm{mg} / \mathrm{kg}$ dose of $\mathrm{T}$. schimperi oil showed $50 \%$ mortality indicating that its LD50 is about $2,000 \mathrm{mg} / \mathrm{kg}$. However, Sub-acute toxicity study of $T$. schimperi on mice did not cause major organ damage (liver and kidney) and rise in serum enzyme level as compared with the control group plus the ointment prepared from essential oil of T. schimperi which did not show any abnormal skin irritation up on follow up for 14 days. Destaw, et al. [38] also investigated that essential oils of Burning sensations and the most irritation in mice oil was observed during acute oral toxicity study on Alamata (thymol chemo type) oil. The carvacrol chemo-types (Yilmana and Butajira) resulted in reduced growth of mice than did the thymol chemo-types (Ofla, Alamata, Tarmaber, and Bale). The LD50 of the essential oils are in $2,000 \mu \mathrm{L} / \mathrm{Kg}$ to $5,000 \mu \mathrm{L} / \mathrm{Kg}$ dose ranges of body weight of the test mice which was comparable to with the study of other types of thymus species of essential oils of T. algeriensis [39]. Acute toxicity study on $5000 \mathrm{mg} / \mathrm{kg}$ oral limit dose of aqueous extract of $T$. schimperi leaves showed no clinical signs of toxicity, mortality and behavioral changes [32] whereas, n-butanol fraction of the aqueous crude extract and crude methanol leaf extract of T. serrulatus with the oral limit dose of $5,000 \mathrm{mg} / \mathrm{kg}$ showed no sign of toxicity and overt behavioral changes [22,25]. Nigatu, et al. [7] report on intra gastric uptake of extracts at doses 300, 2,000, 5,000 , and $10,000 \mathrm{mg} / \mathrm{kg}$ did not produce any sign of morbidity and mortality in female mice during the acute toxicity study time period and showed that the LD50 of the aqueous leaf extracts of T. serrulatus were above $10,000 \mathrm{mg} / \mathrm{kg}$. He also studied the chronic effect of aqueous leaf extract of T. serrulatus on the general body weight of the mice which showed the overall increment in body weight with time and the concentration of Urea/BUN its level decreased considerably at doses of $200 \mathrm{mg} / \mathrm{kg}(46.66 \pm 2.08)$ and $600 \mathrm{mg} / \mathrm{kg}(34.6 \pm 3.05)$ compared with the control groups $(53.33$ $\pm 3.05)$. The study of the gross appearance of internal organs (kidney and liver) of treated mice and rat showed no abnormal changes in shape, texture, size or color compared to the control.
In another report the methanol and aqueous crude extracts of T. schimperi showed no morbidity 14 days (acute toxicity) at dose of $2 \mathrm{~g} / \mathrm{kg}$ body weight which signifies that the LD50 could be greater than $2 \mathrm{~g} / \mathrm{kg}$ per body weight in mice [34].

\section{Efficacy of T. schimperi and T. serrulatus}

T. serrulatus with $80 \%$ methanol crude extract have sown an increase urine volume. Doses of $125 \mathrm{mg} / \mathrm{kg}$ and $500 \mathrm{mg} / \mathrm{kg}$ were the lowest and the highest urinary excretions with a diuretic index of 1.13 and 1.60 respectively. $88 \%$ at $500 \mathrm{mg} / \mathrm{kg}$ diuretic activity has been recorded from the extract. T. Serrulatus crude extract from n-butanol fraction of the $80 \%$ methanol also increased urine volume and the highest diuretic index $(\mathrm{P}<0.01)$ was evident at $1000 \mathrm{mg} / \mathrm{kg}$ which was even greater than that of the HCT. The $80 \%$ methanol crude extract of $T$. Serrulatus showed the prominent natriuresis at $500 \mathrm{mg} / \mathrm{kg}(\mathrm{P}<0.001)$, and $125 \mathrm{mg} / \mathrm{kg}$ was the lowest amount recorded. The chloroform fraction of the crude extract did not show significant urinary excretion of both Sodium and Potassium ions. However, showed significant kaliuresis only at $1000 \mathrm{mg} /$ $\mathrm{kg}(\mathrm{P}<0.05)$. A dose-dependent increase in the urinary excretion of Sodium and Potassium ions were observed from n-butanol fraction of the $80 \%$ methanol extract of T. serrulatus. At the dose of $1000 \mathrm{mg} / \mathrm{kg} \quad(\mathrm{P}<0.001$ and $\mathrm{P}<0.01$, respectively) the highest natriuresis and kaliuresis were observed [25].

Amelework, et al. [22] study revealed that the crude aqueous extract of $T$. serrulatus increased the urine volume at the dose of $250 \mathrm{mg} / \mathrm{kg},(1,000 \mathrm{mg} / \mathrm{kg})$ which is the lowest and the highest urine output was recorded respectively, with a considerable diuretic activity of 92 percent in comparison with the standard drug, HCT (hydrochlorothiazide). The dichloromethane fraction of the aqueous extract of $T$. serrulatus failed to increase in urinary output at 2,50,500, and $1,000 \mathrm{mg} / \mathrm{kg}$ doses but, the $\mathrm{n}$-butanol fraction increased the urine output at all test doses $(2,50,500$, and 1,000 $\mathrm{mg} / \mathrm{kg}$ ). Even the lowest test dose of $\mathrm{n}$-butanol fraction exhibited a significant $(\mathrm{P}<0.05)$ diuretic activity of $70 \%$ and the highest diuretic activity of the fraction was demonstrated at $1,000 \mathrm{mg} / \mathrm{kg}$, which was about $94 \%$.

According to Bekesho, et al. [8] in vitro vasodilatory effect of aqueous leaf extract of T. serrulatus on thoracic aorta of Guinea pigs. Sequential administrations of relatively low to high concentrations of T. serrulatus aqueous leaf extract $(0.5-5 \mathrm{mg} / \mathrm{mL})$ to the organ bath fluid significantly ( $\mathrm{P}<0.001$, in all cases) attenuated the force of contractions on thoracic aorta of guinea pigs, which were provoked by $\mathrm{KCl}$ in concentration dependent manner both in intact $(\mathrm{n}=5)$ and denuded $(n=5)$ endothelium. The percent of aorta relaxation of the T. serrulatus aqueous leaf extract showed a significant $(\mathrm{P}<0.05)$ difference between intact and denuded endothelium of the guinea pigs thoracic aorta with a statistical mean of $(43.10 \pm 0.52) \%$ and $(35.60 \pm 0.52) \%$ respectively.

Aqueous and methanol $80 \%$ extract of T. schimperi showed a reduction in blood glucose levels in a dose- and time-dependent manner. T. schimperi aqueous extracts of 250 and $500 \mathrm{mg} / \mathrm{kg}$ showed reduction of $22.65 \%$ and $33.15 \%$ in plasma glucose levels, respectively after $4 \mathrm{~h}$ of extract administration and In case of $80 \%$ methanol extraction at 250 and $500 \mathrm{mg} / \mathrm{kg}$ showed reduction of $30.06 \%$ and $38.35 \%$ in plasma glucose levels, respectively [34]. The oral administration of aqueous extract of $T$. schimperi leaves and its essential oil distillate at doses of (250, 500, 750 and $1000 \mathrm{mg} / \mathrm{kg})$ and $(1$ and $1.5 \mathrm{ml} / \mathrm{kg}$ ) was respectively evaluated for 
their diuretic and anti-hypertensive activity against salt-sucrose induced hypertensive rats. The aqueous extract of T. schimperi leaves for all mentioned doses showed positive diuretic activity at $5 \mathrm{hr}$ and the two higher doses significantly increased $\mathrm{Na}^{+}, \mathrm{K}^{+}$and $\mathrm{Cl}^{-}$content of urine (Figure 1) [32].

A $50 \mathrm{mg} / \mathrm{ml}$ concentration Ethanol, Methanol and Chloroform extract of $T$. schimperi showed antibacterial activity against standard and clinical isolates of human pathogenic bacteria [40] which was similar pharmacologic activity with other species of thymus [28,41]. Ethanol and Methanol extract inhibited gram positive bacteria MRSA, S. aureus, S. pneumoniae (standard) and S. pneumoniae (clinical isolate). Methanol extract showed higher $(\mathrm{P}<0.05)$ inhibition zone against the tested bacteria (E. coli, MRSA, S. flexneri, S. aureus, K. pneumonia (clinical isolate), S. pneumoniae, and S. pneumoniae (clinical isolate) as compared to ethanol extract. However, Chloroform extract showed 100\% inhibition against all the tested bacteria with higher inhibition zone for most of test bacteria except for standard S. aureus $(17 \mathrm{~mm})$. The maximum inhibition zone of Ethanol extract $(19 \mathrm{~mm})$ was recorded for MRSA and standard S. pneumoniae while the minimum was obtained for standard S. aureus $(17 \mathrm{~mm})$. Similarly, the maximum inhibition zone for methanol extract was obtained for MRSA $(19.3 \mathrm{~mm})$ whilst the minimum was obtained for standard S. aureus $(18.3 \mathrm{~mm})$. MRSA showed highest inhibition zone with chloroform extract as compared to other test bacteria and the MIC value for chloroform extract ranged from $6.25 \mathrm{mg} / \mathrm{ml}$ to $12.5 \mathrm{mg} / \mathrm{ml}$. Five of test bacteria (MRSA, S. flexneri, K. pneumoniae, S. pneumoniae standard and clinical isolate) got high MIC value (12.5) whilst only two of test organisms (E. coli and S. aureus) showed lowest MIC value $(6.25 \mathrm{mg} / \mathrm{ml})$. However, the minimum $\mathrm{MBC}$ value was $6.25 \mathrm{mg} / \mathrm{ml}$ while, the maximum value was $25 \mathrm{mg} / \mathrm{ml}$. The highest MBC value $(25 \mathrm{mg} / \mathrm{ml})$ was obtained for three test bacteria (K. pneumoniae, clinical $S$. pneumoniae and standard S. pneumoniae). The lowest $\mathrm{MBC}$ value $(6.25 \mathrm{mg} / \mathrm{ml})$ was recorded only for E. coli.

T. schimper oil had moderate antibacterial effect on tested Enterobactericeae; $17 \mathrm{~mm}$ and $24 \mathrm{~mm}$ inhibition zone in diameter against $E$. coli and $K$. pneumoniae respectively. It had also considerable inhibition zone in diameter; MSSA and MRSA (24 mm) [42]. Mohammed, et al. [43] on the other study, reported that $T$. schimperi had the greatest inhibition zone diameter of $88.66 \mathrm{~mm}$ against $R$. rubra and $73.33 \mathrm{~mm}$ against clinical isolates of Tricophyton species and Microsporum species. The least inhibition

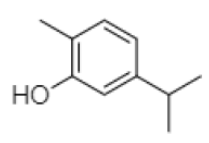

Carvacrol

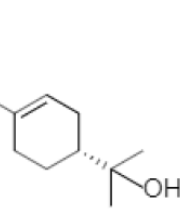

$\alpha$-Terpineol

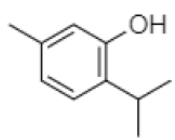

Thymol
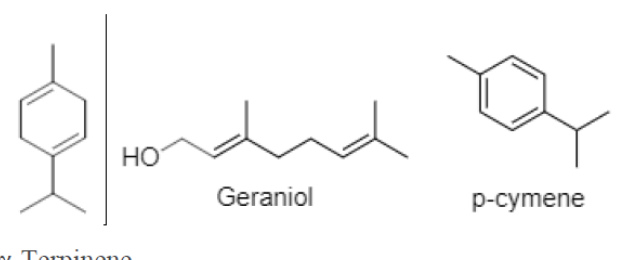

Figure 1: Some of the chemical structures for potentially active compounds of thymus species in Ethiopia. zone exhibited by T. schimperi was $35.66 \mathrm{~mm}$ against C. albicans. T. schimperi essential oil possessed potential antibacterial activity against Bacillus, E. coli, Shigella and Streptococcus species when Bacteria susceptibility to the essential oils was studied by the agar diffusion method. T. schimperi oils highest antibacterial activity was $90 \mathrm{~mm}$ in E. coli, Shigella species and Streptococci and relatively least activity was recorded in Bacillus species to be $63 \mathrm{~mm}$.

The highest MIC values of T. schimpri oil was $0.08 \mu \mathrm{l} / \mathrm{ml}$ against Tricophyton species (scalp isolate), Microsporum and R. rubra species. T. schimperi oil showed activities in the range of concentration from $0.31 \mu \mathrm{l} / \mathrm{ml}$ to $0.63 \mu \mathrm{l} / \mathrm{ml}$ which is comparable with other species of thymus [44]. T. serpyllum essential oil showed the strongest activity in both cases (MIC 2.5-5 $\mu \mathrm{g} / \mathrm{mL}$, MBC 5-10 $\mu \mathrm{g} / \mathrm{mL}$; MIC $1-2 \mu \mathrm{g} / \mathrm{mL}$, MFC $2-4 \mu \mathrm{g} / \mathrm{mL}$ ). T. algeriensis inhibited the growth of selected microorganisms in medium range of MIC $20-80 \mu \mathrm{g} / \mathrm{mL}$, MBC 40 $160 \mu \mathrm{g} / \mathrm{mL}$ (for bacteria) and MIC 5-10 $\mu \mathrm{g} / \mathrm{mL}$, MFC 10-20 $\mu \mathrm{g} / \mathrm{mL}$ (for fungi). The essential oils of $T$. serpyllum, T. algeriensis and T. vulgaris showed significant antibacterial activity, especially against $S$. mutans, a recognized cariogenic species and their oils also efficiently inhibited the growth of Candida species

Shewaye, et al. [3] studied the antifungal activity of the oil of T. schimperi against Aspergillus niger. The essential oil of T. schimperi indicated strong effect on the fungal pathogen (Aspergillus niger) after applying $10 \mu \mathrm{L} /$ disc of the oil, which completely inhibited up to a diameter of $36 \mathrm{~mm}$ and its minimum inhibitory concentration (MIC) was estimated to be lower than $5 \mu \mathrm{L} /$ disc, which was related with other finding [45]. This is due to the presence of thymol and carvacrol as observed from GC and GC/MS analysis. Awol et al. [11] study, the oil of $T$. schimperi has shown the greatest inhibition zone diameter of $33 \mathrm{~mm}$ against S. epidermidis bacteria and inhibited the growth of two Trichophyton and two Aspergillus species at a concentration lower than $15.75 \mathrm{mg} / \mathrm{mL}$. Higher concentration (23.25 mg/mL) of T. schimperi essential oil inhibits the growth of $P$. aeruginosa which was comparable with the essential oil of T. kotschyanus species [46].

The oils of T. schimperi and T. serrulatus from different Ethiopian localities had promising protective activity against paracetamol induced hepatic damage in rats. Treatment with $200 \mu \mathrm{L} / \mathrm{kg}$ of the essential oils of T. schimperi (Tarmaber) and T. serrulatus (Yilmana, Alamata) was found to reverse increased levels of AST, ALT and ALP in PAR (paracetamol) treated rats [30].

\section{Pharmacological properties of T. schimperi and T. serrulatus}

The oils of T. schimperi possess antifungal and antibacterial activity against different species of fungus and bacteria [3,11,40,43] which was similar with pharmacologic activity of oils of T. hirtus, T. kotschyanus boiss, T. vulgaris, T. mastichina, T. serpyllum and T. algeriensis species $[28,41,46,47]$. T. schimperi oil had antioxidant and preservative effects [4] and consistent with other species of thymus $[2,41,44,46,48,49]$ and seem to be applicable in both medicine and food industry. The oils of T. serrulatus and T. schimperi from different Ethiopian localities had promising protective activity against paracetamol induced hepatic damage in rats [30]. T. schimperi was one of Ethiopian anticancer plants since it has antioxidant properties [50]. Diuretic activity was observed from the aqueous, $80 \%$ methanol crude extract and its different solvent 
Table 1: Ethno botanical studies of T. schimperi and T. serrulatus.

\begin{tabular}{|c|c|c|c|c|c|}
\hline Parts used & $\begin{array}{l}\text { Plant Species } \\
\text { used }\end{array}$ & $\begin{array}{l}\text { Disease } \\
\text { treated }\end{array}$ & Method of preparation & Mechanism of action & Reference \\
\hline Leaf & $\begin{array}{l}\text { T. schimperi } \\
\text { Ronniger }\end{array}$ & Abdominal disease & $\begin{array}{l}\text { Concocted, crushed and mixed with } \\
\text { milk }\end{array}$ & $\begin{array}{l}\text { Inhibit the growth of pathogenic } \\
\text { microorganism }\end{array}$ & [53] \\
\hline \multirow{2}{*}{ Leaf } & \multirow{2}{*}{$\begin{array}{l}\text { T. schimperi } \\
\text { Ronniger }\end{array}$} & \multirow{2}{*}{ Cough } & Powdered, mix with & \multirow{2}{*}{$\begin{array}{l}\text { Reduce the surface tension and viscosity } \\
\text { of the mucus }\end{array}$} & \multirow{2}{*}{ [56] } \\
\hline & & & water and drunk & & \\
\hline Leaf & \multirow{2}{*}{$\begin{array}{l}\text { T. schimperi, } \\
\text { T. serrulatus }\end{array}$} & \multirow{2}{*}{ Blood pressure } & \multirow{2}{*}{ Dried crushed and drunk as tea } & \multirow{2}{*}{$\begin{array}{l}\text { Blocks the alpha receptor and relax the } \\
\text { muscles }\end{array}$} & \multirow{2}{*}[23]{} \\
\hline Flower & & & & & \\
\hline Leaf & \multirow{2}{*}{$\begin{array}{l}\text { T. schimperi, } \\
\text { T. serrulatus }\end{array}$} & General pain & \multirow[b]{2}{*}{ Dried, crushed and drunk as tea } & \multirow{2}{*}{$\begin{array}{l}\text { By binding to protein targets on cell } \\
\text { membranes and affecting the biochemical } \\
\text { processes of the body }\end{array}$} & \multirow{2}{*}[23]{} \\
\hline Flower & & syndrome & & & \\
\hline $\begin{array}{l}\text { Leaf } \\
\text { Flower }\end{array}$ & $\begin{array}{l}\text { T. schimperi, } \\
\text { T. serrulatus }\end{array}$ & Influenza & Dried, crushed and drunk as tea & Inhibits polymerase acidic endonuclease & {$[23]$} \\
\hline Aerial parts & $\begin{array}{l}\text { T. schimperi, } \\
\text { T. serrulatus }\end{array}$ & Abdominal pain & Dried, crushed and drunk as tea & $\begin{array}{l}\text { Inhibit the growth of pathogenic } \\
\text { microorganism }\end{array}$ & {$[15,23]$} \\
\hline Leaf & $\begin{array}{l}\text { T. schimperi, } \\
\text { T. serrulatus }\end{array}$ & Ascariasis & Dried, crushed and drunk as tea & Inhibits tubulin polymerization & {$[23]$} \\
\hline Whole plant & T. schimperi & Snake bite & Drunk orally, body wash & $\begin{array}{l}\text { Reducing systemic toxicity by limiting } \\
\text { lymphatic flow }\end{array}$ & {$[55]$} \\
\hline Stem & T. schimperi & Devil Disease & Drunk orally, body wash & Inhibit abnormal cell growth & {$[55]$} \\
\hline Root & T. schimperi & Intestinal parasite & Drunk orally & Inhibit the growth of parasite & {$[55]$} \\
\hline Whole plant & T. schimperi & Toothaches & Chew it with the affected tooth & $\begin{array}{l}\text { Resist acid and block the cavity } \\
\text { forming action of bacteria }\end{array}$ & {$[15]$} \\
\hline Leaf & T. schimperi & Hypertension & Boiled leaves and drunk as tea & prevent aldosterone release & {$[56]$} \\
\hline Leaf & T. schimperi & Whooping cough & Boiled leaves and drunk as tea & $\begin{array}{l}\text { reduce the surface tension and viscosity of } \\
\text { the mucus }\end{array}$ & {$[56]$} \\
\hline Root & T. schimperi & hypertension & $\begin{array}{l}\text { Root dried, powdered, and drink with } \\
\text { tea }\end{array}$ & prevent aldosterone release & {$[54]$} \\
\hline Leaf & $\begin{array}{l}\text { T. schimperi } \\
\text { Ronniger }\end{array}$ & Cancer & Dry leaves are decocted and drunk & Inhibit the abnormal growth of cells & {$[50]$} \\
\hline $\begin{array}{l}\text { Leaf and } \\
\text { Flower }\end{array}$ & T. serrulatus & Renal disease & $\begin{array}{l}\text { Fresh leaves are soaked with hot water } \\
\text { and the filtrate taken orally }\end{array}$ & $\begin{array}{l}\text { reduced renal inflammation, cellular } \\
\text { infiltration and fibrosis }\end{array}$ & [32] \\
\hline $\begin{array}{l}\text { Stem, Leaf, } \\
\text { Whole plant }\end{array}$ & $\begin{array}{l}\text { T. schimperi, } \\
\text { T. serrulatus }\end{array}$ & Diabetes & $\begin{array}{l}\text { Dried stem and leaf powder boiled with } \\
\text { tea is given orally }\end{array}$ & Reduce intestinal glucose absorption & {$[56]$} \\
\hline
\end{tabular}

fractions of the leaves of T. serrulatus [22,25] and also vasodilatory effect on $\mathrm{KCl}$ induced pre contracted guinea pigs' isolated thoracic aorta rings which might result to antihypertensive effect [8]. T. vulgaris oil showed proliferation inhibition of human cancer cell lines in dose dependent manner [51], T. algeriensis possesses gastro protective effect resulted in maintaining the mucosal integrity and a mild mucosal ulceration at a dose of 117 and $180 \mathrm{mg} / \mathrm{kg}$ respectively [39].

T. serpyllum had potent effect on inhibition of human tumor cells lines growth [44]. T. longicaulis, T. pulegioides, T. vulgaris, T. serpyllum, T. striatus and T. praecox also showed anti-acetylcholinesterase activities [2]. All this entire species of thymus had comparable pharmacologic property with $T$. schimperi and T. serrulatus.

\section{Ethno-medicinal uses of T. schimperi and T. serrulatus}

Ethnobotanical study and knowledge of medicinal plants would contribute to improved human health on a local and/or a global level [52]. In west highlands of Ethiopia T. schimperi is one of herbal spices grown in home garden and used as ingredients of mixed spice used in cooking and medicinally important [53] which was consistent with the previous report [54]. T. serrulatus grown in Tigray used as ascaricidal, intestinal paraciticidal and both of T. schimperi and $T$. serrulatus used for treatment of general pain syndrome, blood pressure, influenza and abdominal pain [53], which was similar to ethnobotanical use of T. serphyllum species in in Pakistan [55]. T. serphyllum used as laxative, a good tonic for the kidney and eye diseases, useful in bronchitis and purify the blood in Sudan [56]. T. schimperi was used not only for human disease, but also for cattle and its flower for honey around Odo Bulu, Bale and Demaro region of Ethiopia [52]. T. schimperi is also used for treatment of circulatory disorder in Ada'a District, East Shewa Zone of Oromia Regional State, Ethiopia [56].

In the overall our ethnobotanical review data in Table 1 reveals that, most Ethiopian community utilized T. schimperi and T. serrulatus for the managements of different types of diseases especially in rural communities of the country.

\section{CONCLUSION AND RECOMMENDATION}

This review highlighted phytochemical-constituents, safety and efficacy study of Thymus schimperi and Thymus serrulatus which were endemic species represented in Ethiopia. T. schimperi and T. serrulatus belong to the thymol-carvacrol chemo-types. The 
isolation yield and the chemical composition of the thyme oil are dependent on the environment, growth region, cultivation practices, and the development stage of the plant, habitat and harvesting time. The essential oils of $T$. schimperi possess antibacterial, antifungal, antioxidant and preservative effects. This review also showed the diuretic and vasodilatory effect of T. serrulatus which was safe and effective. The leaves of T. schimperi was widely used for different ailments at different parts of Ethiopia and more frequently cited by ethno-botanical study than T. serrulatus. Even though, the acute toxicity study of the essential oils of $T$. schimperi did not cause increase in serum enzyme level and major organ damage (liver and kidney), it causes 50 percent mortality at the dose of $2,000 \mathrm{mg} / \mathrm{kg}$. The n-butanol fraction of crude aqueous extract of $T$. serrulatus increase urine volume and the highest urine output was observed at the highest dose $(1,000$ $\mathrm{mg} / \mathrm{kg}$ ) with an appreciable diuretic activity $94 \%$. Further chemical isolation, dosage form development, clinical trial and toxicological study is recommended for both species.

\section{CONFLICT OF INTEREST}

The author has declared that there is no conflict of interest with regarding to the authorship and publication of this review article.

\section{REFERENCES}

1. Casiglia S, Bruno M, Senatore F, Scandolera E, Senatore F. Influence of harvesting time on composition of the essential oil of Thymus capitatus (L.) Hoffmanns. Arab J Chem. 2015 (Inpress)

2. Kindl M, BlaDekoviT B, Bucar F, Vladimir-KneDevi TS. Antioxidant and Anticholinesterase Potential of Six Thymus Species. Evid Based Complement Alternat Med. 2015;10.

3. Hailemariam GA, Emire SA. Antioxidant Activity and Preservative Effect of Thyme (Thymus Schimperi R.) British J Appl Sci Technol. 2013;3:1311-1326.

4. Asfaw N, Storesund HJ, Skattebo L, To F, Aasen AJ. 12-Volatile oil constituents of two Thymus species from Ethiopia. Flavour Fra ` $\mathrm{r}$ 1999;15:123-125.

5. Dagne E, Hailu SL, Bisrat D, Tadele W. Constituents of the essential oil of Thymus schimperi. Bull Chem Soc Ethiop. 1998;12:79-82.

6. Debelo N, Afework M, Debella A, Makonnen E, Ergete W, Geleta B. Histopathological and Biochemical Assessment of Chronic Oral Administration of Aqueous Leaf Extract of Thymus Serrulatus in Mice. Clin Exp Pathol. 2015;5.

7. Geleta B, Eyasu M, Kebamo S, Debella A, Makonnen E, Abebe A. Invitro vasodilatory effect of aqueous leaf extract of Thymus serrulatus on thoracic aorta of Guinea pigs. Asian Pacific J Trop Biomed. 2015;5:15-18.

8. Awraris D, Bhagwan SC. Investigation of the levels of selected metals in the leaves of Thyme (T. schimperi and T. vulgaris) Grown in Ethiopia. Springer. 2011;141:317-328.

9. https://www.who.int/nmh/publications/ncd-profiles-2018/en/

10. Mekonnen A, Yitayew B, Tesema A, Taddese S. In Vitro Antimicrobial Activity of Essential Oil of Thymus schimperi, Matricaria chamomilla, Eucalyptus globulus, and Rosmarinus officinalis. Int J Microbiol. 2016;2016.

11. Bekalo TH, Woodmatas SD, Woldemariam ZA. An ethnobotanical study of medicinal plants used by local people in the lowlands of Konta Special Woreda, southern nations, nationalities and peoples regional state, Ethiopia. J Ethnobiol Ethnomed 2009;5:26

12. Chekole G. Ethnobotanical study of medicinal plants used against human ailments in Gubalafto. J Ethnobiol Ethnomed. 2017;13:55.

13. Teklay A, Abera B, Giday M. An ethnobotanical study of medicinal plants used in Kilte Awulaelo District, Tigray Region of Ethiopia. J Ethnobiol Ethnomed. 2013;9:65.

14. Giday M, Asfaw Z, Woldu Z, Teklehaymanot T. Medicinal plant knowledge of the Bench ethnic group of Ethiopia : an ethnobotanical investigation. J Ethnobiol Ethnomed. 2009;5:34.

15. Tolossa K, Debela E, Athanasiadou S, Tolera A, Ganga G. Ethnomedicinal study of plants used for treatment of human and livestock ailments by traditional healers in South Omo, Southern. J Ethnobiol Ethnomed. 2013;9:1.

16. Wubetu M, Abula T, Dejenu G. Ethnopharmacologic survey of medicinal plants used to treat human diseases by traditional medical practitioners in Dega Damot district, Amhara, Northwestern. BMC Res Notes. 2017;1-13.

17. State R, Megersa M, Asfaw Z, Kelbessa E, Beyene A, Woldeab B. An ethnobotanical study of medicinal plants in Wayu Tuka District, East Welega Zone of Oromia. J Ethnobiol Ethnomed. 2013;9:1.

18. Nigatu TA, Afework M, Urga K, Ergete W, Makonnen E. Toxicological investigation of acute and chronic treatment with Gnidia stenophylla Gilg root extract on some blood parameters and histopathology of spleen, liver and kidney in mice. BMC Res Notes. 2017;1-13.

19. Tefera BN, Kim Y. Ethnobotanical study of medicinal plants used as antimalarial and repellent by Sidama people of Hawassa Zuria district, Southern Ethiopia. J Complement Med Res. 2019;10:13-26.

20. Melka AE, Makonnen E, Debella A, Fekadu N, Geleta B. Diuretic activity of the aqueous crude extract and solvent fractions of the leaves of Thymus serrulatus in mice. J Exp Pharmacol. 2016;61-67.

21. Damtie D, Mekonnen Y. Thymus species in Ethiopia : Distribution, medicinal value, economic benefit, current status and threatening factors. Ethiop J Sci Technol. 2015;8:81-92.

22. Melka AE, Makonnen E, Debella A, Fekadu N, Geleta B. Evaluation of Diuretic Activity of Methanol Crude Extract of Thymus serrulatus Leaves and its Solvent Fraction in Mice. Biol Med. 2016;8:5-10.

23. Borug O, Jianu C, Gole I, At G, Fg H. Thymus vulgaris essential oil : Chemical composition and antimicrobial activity. J Med Life. 2014; 7:56-60.

24. Jaric S, Mitrovic M, Pavlovic P. Review of ethnobotanical, phytochemical, and pharmacological study of Thymus serpyllum L. Evidence-Based Complement Alt Med. 2015;2015.

25. Damtie D, Braunberger C, Conrad J, Beifuss U. Composition and hepatoprotective activity of essential oils from Ethiopian thyme species (Thymus serrulatus and Thymus schimperi). J Essent Oil Res. 2018:1-9.

26. Delgado-ada J. Chemical composition and bioactivity of essential oils from flower and fruit of Thymbra capitata and Thymus species. J Food Sci Technol. 2017;54:1857-1865.

27. Meresa A. An Ethno botanical review on medicinal plants used for the management of hypertension. J Clin Exp Pharmacol. 2017;7.

28. Hossain MA, AL-Raqmi KA, AL-Mijizy ZH, Weli AM, Al-Riyami Q. Study of total phenol, flavonoids contents and phytochemical screening of various leaves crude extracts of locally grown Thymus vulgaris. Asian Pac J Trop Biomed. 2013;3:705-710.

29. Melesie G. Evaluation of hypoglycemic and antihyperglycemic effect of aqueous and $80 \%$ methanol leaves extracts of Thymus schimperi (Lamiaceae) in mice. Addis Ababa Univ Lib. 2018.

30. Kassegn HH. Inorganic and phytochemical content analysis of the wild abyssinian thyme spice. Food Sci Qua Manage. 2016;50:82-85.

31. Derbie A, Chandravanshi BS. Concentration Levels of Selected Metals 
in the Leaves of Different Species of Thyme (T. schimperi and T. vulgaris) Grown in Ethiopia. Biol Trace Elem Res. 2011;317-328.

32. Dires K, Mengist B, Lulekal E. Evaluation of acute, sub-acute and skin irritation toxicity on Essential Oil. J Clinical Tox. 2018;8:8-11.

33. Damtie D, Mekonnen Y, Eyado AN. Acute oral toxicity study of Thymus serrulatus and Thymus schimperi from Ethiopia. Ethiop J Sci Technol. 2017;10:181-192.

34. Guesmi F, Ben AM, Barkaoui T, Tahri W, Mejri M, Ben-attia M. Effects of Thymus hirtus sp. algeriensis Boiss. et Reut. (Lamiaceae) essential oil on healing gastric ulcers according to sex. Lipids Health and Dis. 2014;13:138.

35. Bekele A, Abera R, Mebratu T, Dessie W, Getu A. Antimicrobial activity of Thymus schimperi Ronninger (Lamiaceae) against standard and clinical isolates of human pathogenic bacteria. J Med Plants Res. 2015;9:379-384.

36. Fatma G, Mouna BF, Mondher M, Ahmed L. In-vitro assessment of antioxidant and antimicrobial activities of methanol extracts and essential oil of Thymus hirtus sp. algeriensis. Lipids Health Dis. 2014;13:114

37. Gadisa E, Weldearegay G, Desta K, Tsegaye G, Hailu S, Jote K. Combined antibacterial effect of essential oils from three most commonly used Ethiopian traditional medicinal plants on multidrug resistant bacteria. BMC Comp Alt Med. 2019;19:24.

38. Nasir M, Tafess K, Abate D. Antimicrobial potential of the Ethiopian Thymus schimperi essential oil in comparison with others against certain fungal and bacterial species. BMC Comp Alt Med. 2015;15:260.

39. Nikolic M. Chemical composition, antimicrobial, antioxidant and antitumor activity of Thymus serpyllum L., Thymus algeriensis Boiss. $\mathcal{E}$ Reut and Thymus vulgaris L. essential oils. Ind Crops Prod. 2014;52:183. 190.

40. Behnia M, Haghighi A, Komeylizadeh H, Tabaei SS, Abadi A. Inhibitory Effects of Iranian Thymus vulgaris Extracts on in Vitro Growth of Entamoeba histolytica. Korean J Parasitol. 2008;46:153. 156.

41. Baharfar R, Azimi R, Mohseni M. Antioxidant and antibacterial activity of flavonoid-, polyphenol- and anthocyanin-rich extracts from Thymus kotschyanus boiss $\mathcal{E}$ hohen aerial parts. J Food Sci Technol. 2015;52:6777-6783.

42. Cutillas A, Carrasco A, Martinez-gutierrez R, Tomas V, Tudela J. Thymus mastichina L. essential oils from Murcia (Spain): Composition and antioxidant, antienzymatic and antimicrobial bioactivities. PLOSONE. 2018;1-19.

43. Sa SCB. Chemical composition and antioxidant activity of Thymus vulgaris $\mathrm{L}$. volatile oil obtained by two different methods. 2010;15(4):5436-43.

44. Zuberi MI, Kebede B, Gosaye T, Belachew O, Kefalew A. Antioxidant and $\alpha$-amylase inhibition activities in vitro of various solvent extracts of Thymus schimperi Ronniger. Mutat Res-Genet Toxicol Environ Mutagen. 2015;753:81-92.

45. Esubalew ST, Belete A, Lulekal E, Gabriel T, Engidawork E, Asres K. Review of Ethnobotanical and Ethnopharmacological Evidences of some Ethiopian Medicinal Plants traditionally used for the Treatment of Cancer. Ethiop J Health Dev. 2017;31.

46. Ayesh BM, Abed AA, Faris DM. In vitro inhibition of human leukemia THP-1 cells by Origanum syriacum L. and Thymus vulgaris L. extracts. BMC Res Notes. 2014;7:612.

47. Heinrich M,EdwardsS, Moerman DE, LeontiM.Ethnopharmacological field studies: A critical assessment of their conceptual basis and methods. J Ethnopharmacol. 2009;124:1-17.

48. Zuberi MI, Kebede B, Gosaye T, Belachew O. Species of herbal spices grown in the poor farmers home gardens of West Highlands of Ethiopia : An Ethnobotanical account. 2014;4:164-185.

49. Aziz MA, Adnan M, Khan AH, Shahat AA, Al-said MS, Ullah R. Traditional uses of medicinal plants practiced by the indigenous communities at Mohmand Agency, FATA, Pakistan. J Ethnobiol Ethnomed. 2018;14:2.

50. Bussmann RW, Swartzinsky P, Worede A, Evangelista P. Plant use in Odo-Bulu and Demaro, Bale region, Ethiopia. J Ethnobiol Ethnomed. 2011;1-21.

51. Kefalew A, Asfaw Z, Kelbessa E. Ethnobotany of medicinal plants in Ada' a District, East Shewa Zone of Oromia Regional State. J Ethnobiol Ethnomed. 2015;11:25.

52. Yineger H, Kelbessa E, Bekele T, Lulekal E. Plants used in traditional management of human ailments at bale mountains plants used in traditional management of human ailments at Bale Mountains National Park, Southeastern Ethiopia. J Med Plants Res. 2008;2:132. 153.

53. Alemayehu G, Asfaw Z, Kelbessa E. Ethnobotanical study of medicinal plants used by local communities of Minjar-Shenkora District, North Shewa Zone of Amhara Region, Ethiopia. J Med Plants Stud. 2015;3:111.

54. Teklehaymanot T. An ethnobotanical survey of medicinal and edible plants of Yalo Woreda in Afar regional state, An ethnobotanical survey of medicinal and edible plants of Yalo Woreda in Afar regional state, Ethiopia. J Ethnobiol Ethnomed. 2017;5:40.

55. Avigdor E, Wohlmuth H, Asfaw Z, Awas T. The current status of knowledge of herbal medicine and medicinal plants in Fiche, Ethiopia The current status of knowledge of herbal medicine and medicinal plants in Fiche, Ethiopia. J Ethnobiol Ethnomed. 2014;10:1-32.

56. Meresa A. Herbal Medicines for the Management of Diabetic Mellitus in Ethiopia and Eretria including their Phytochemical Constituents. Am J Adv Drug Del. 2017;5:40-58. 